$$
\text { SGP-TR-57 }
$$

\title{
EFFECTS OF WATER INJECTION INTO FRACTURED GEOTHERMAL RESERVOIRS: A SUMMARY OF EXPERIENCE WORLDWIDE
}

Roland N. Horne

June 1982

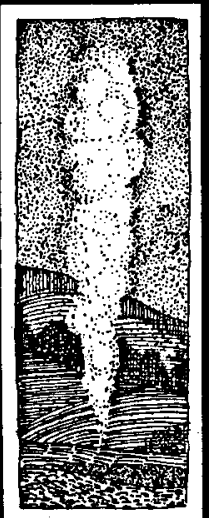

Stanford Geothermal Program

INTERDISCIPLINARY RESEARCH IN ENGINEERING AND EARTH SCIENCES

Stanford University, Stanford, California 


\section{DISCLAIMER}

This report was prepared as an account of work sponsored by an agency of the United States Government. Neither the United States Government nor any agency Thereof, nor any of their employees, makes any warranty, express or implied, or assumes any legal liability or responsibility for the accuracy, completeness, or usefulness of any information, apparatus, product, or process disclosed, or represents that its use would not infringe privately owned rights. Reference herein to any specific commercial product, process, or service by trade name, trademark, manufacturer, or otherwise does not necessarily constitute or imply its endorsement, recommendation, or favoring by the United States Government or any agency thereof. The views and opinions of authors expressed herein do not necessarily state or reflect those of the United States Government or any agency thereof. 


\section{DISCLAIMER}

Portions of this document may be illegible in electronic image products. Images are produced from the best available original document. 


\title{
EFFECTS OF WATER INJECTION INTO FRACTURED \\ GEOTHERMAL RESERVOIRS:
}

A SUMMARY OF EXPERIENCE WORLDWIDE

BY

ROLAND N. HORNE

JUNE 1982

\author{
SPONSORED BY \\ THE GEOTHERMAL AND HYDROPOWER TECHNOLOGIES DIVISION \\ OF THE DEPARTMENT OF ENERGY \\ STANFORD-DOE CONTRACT DE-AT03-80SF11459
}


EFEECTS OF WATER INUECTION INTO FRACIURED GEOTHERMAL RESERVOIRS

A sTMLARY OR EXPERIENCE WORLDWIDE

Roland i. Horne

stanford Oniversity

\section{NASTRACT}

Reinjection of water into fractured geothermal reservolis holas potential both for improvenent and degradation of total energy recovery. The replacement of reservolx tluld can mean support of reservolr pressures and also more efficient thermal erergy recovery, bot at the same time the premature invasion of reinfected water back into production wells through high permeability fractures can reduce aischarge enthalpy and hence deliverability and useful energy outgut. Increases in reservoir pressure and maintenance of fleld output have been observed in operating 1lelds, but unforturately so too have premature themal breakthroughs. The design of reinjection schemes, therefore, requires careful Investigation into the likely effects, using field expertmentation. This paper sumarizes fleld experience with reinjection around the world, with the intention of elucidating characteristics of possible problems. The results sumarized in this paper fall into three categories of interest: permeability changes cue to injection (both increases and decreases have been observed); the path followed by injected water las indicated by tracer tests); and the themal and hydraulic influences of infection on the reinfection well itself and on surrounding producers.

\section{INTRODUCIION}

Reinjection of water into geothermal reservoirs during utilization is intended to serve the dual purposes of waste water disposal and improved resource recovery. In order to correctly apportion importance between these two puxposes, it should be noted that reservolx malntenance by reinfection is a controversial subject and in ectual fleld cases to date, water has been reinfected solely for disposal purposes. Reinjection is a nethod of water disposal at the present time, and consideration of reservoir maintenance by relnjection is largely restricted to the uvoidance of detrimental effects.

Commercial scale reinjection in geothermal power plants has been practiced at The Geysers, East Hesa and Brawley. Callfomia, Mhrachapan, Ei Salvador, Mak Ban, Philippines, Larderello, Italy, and in the Eive Japanese flelds; Otake. Onuma, Onikobe, Hatchobara, and Kakkonda. Except for
Iardarello and The Ceysers, all of these fields are 11quid dominated, with producing steam/water ratios between $1: 2$ and $1: 6$. The 11quid-dominated geothermal utllization represents the most difeicult configuration for reinjection, since the quantity of hot water to be disposed of is greater than those of steam-dominated geothermal or conventional thermal generation systems. since almost 11 of the future plasned geothermal utilizations will be of the Ilquid-dominated type. It is of major importance to evaluate current experience in reinjection in this type of system. For example, power stations under construction or plasing with definite conditwents to teinject waste vater include Heber in Callformin; rongonar In the Philippines, groadlands in New zealand; and Nigorikawe in Japan. In adaition, reinjection has been suggested for existing power stations at Cerro Prieto, in Mexico, Fiwi, in the Philippines. and Wairake1, in New zealand.

In terms of its principal role as a means of waste disposal, reinjection is clearly a greater problem when the grantity of water to be reinjected (relative to the useful stean produced) is iarger. However, there are addftional constraints on the physical characterlotics of the injected vater. Due to dissolved solid deposition effects. the temperature of the injected water is a critical parameter. Thus, the evaluation of a reinjection scheme needs to consider the quality. temperature, and chemical nature of the water to be injected.

The supposed benefits of reinjection to the reservolr itself are uswally attributed to the malitenance of reservolr pressure ind masa of fluid in place. In theory. maintaining high reservolr pressures and mass in place should reunce the effects of loss of dellverability, and also those of subsidence or formation collapse. In practice, it has not proved alfficult to keep the reservolr pressures and total dscharge high, however, it is now evident ehat it is important not to recuce discharge enthaloy by reinjection, since if this happens, stean discharge rates will decilne. In fact, recent experlence reported here suggexts the maintenance of alscharge enthalpy is at least os inportant as maintaining reservoir pressure. Aside frow the 1088 in steam production, long-term experience at Walrakel indicates total production also reduces with 
decreasing discharge enthalpy che to the increasing hydrostatic pressure of the fluid in the vell, even though the reservoir pressure at wairake I is now almost constant (Thain, 1981 ).

This paper examines recent experience of reinjection throughout the world. The purpose is to collect all zelevant information to attempt to determine which fields have experienced increases in production cue to refnjection and wich have experienced production declines. In making such a sumary. it is roggested that the nature and extent of reservoir fracturing most afgnificantly affects the outcome of a reinjection scheme. Furthermore, there appears to be a direct cortelatIon between rate of tracer retwrn ouring tracer injection tests and subsequent performance of reinjection schemes. Accordingly, experience wth tracer testing in the same geothermal fields is also sumarlied.

Geothermal flelds examined in this paper include several 1 iquid domirated flelds around the world. These inelude live fields in Japan lotake, Onuma, Onikobe, Hatchobara, and Kakkonda), Ahuachapan In 11 salvador, rongonan in the Phillppines and, wairakei and Broadiands in thev zealand.

Large scale reinfection has also taken place into the vapor-dominated flelds at the Geysers in Calffornia and Larderello in Italy. However. since the results proved somewhat different from those in the 11quid-dominated flelds they have been held over for a separate paper.

This paper will seek the answers to three most important questions in reinjection design:

(a) Can injectivity be maintalned?

(b) There coes the infected water go?

(c) What are the effects on the injection vell itself and on surounding proaucing wells?

\section{NEW ZEALAND}

Injection of vater into newly arilled geothermal wells is standard procedure during conpletion testing in New Zealand. However since 1974, long and medium term injection tests have been carxled out at Broadlands as part of the development design for reinjection for the planned ohak1 power station. In adattion, several vells at Walrakel have experienced a cownhlow of colder vater from shallower to deeper feed depths within the vellbore and have thus constituted an "accidental" injection test.

Injection has taken place into wellB BR7, 13, 23, $28,30,33$ and 34 at Broadiands and the downt 20 Ing wells in Wairakel were wK80, 101, and 107. In all cases at Broadlands except Bp34, injectivity increased with time - probably due to themal contraction of the fissured rock. In BR7 and 28 static formation pressure also fell with injection, probably aus to infection of cooler water into the two-phase reservolx. Tracer returns have shown the infected Kluid in both Broadlands and Watrake1 to migrate over long distances due to the fractured nature of the reservoirs. The tracer movement also seems to be slightly downard; however; since only small percentages of the tracers were ever recovered in any of the tests. it is not clear exactly where the injected water is going.

\section{Broacliands}

Broadlands (Oraki) geothermal fleld was drilled extensively in the inte sixties, alscharged for three years unts 1971 and then shut in. since that time, political and technical deciions concerning its development have been more or less continuously discussed. Reinjection is one of the prominent technical questions at Broadlands since the fleld is blsected by the Walkato Rlver which has a mean watez level only a few meters below lts banks (see Figure 1).: Consegriently any subsidence would cause the river to flood or perhaps even change Its course. The guextion as to where to reinject has not as yet been resolved and several different methods have been trled. including injection lito the fleld itself and injection outside the fleld Into cold ground.

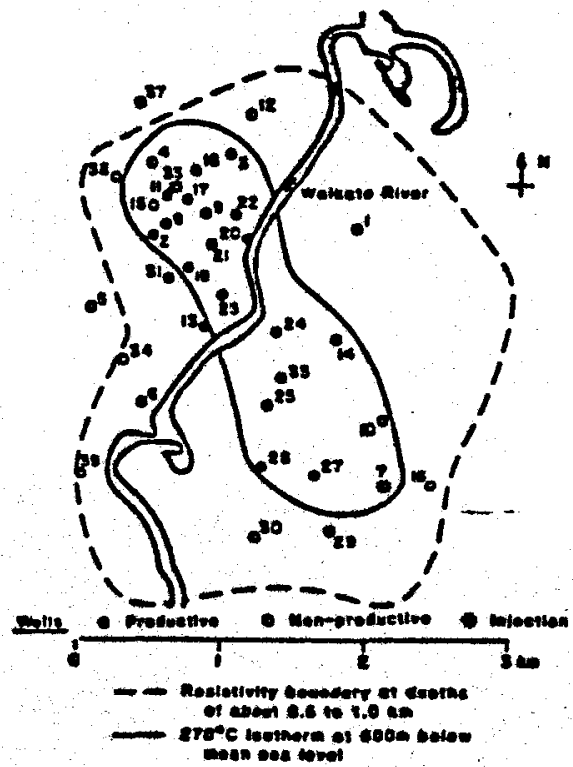

Figure 1. hap of Broadrands (Ohaki) Ceothermal Area

Each has 1ts difficulties, injection into cold ground brings problems with sllica deposition in surface equigment, wellbore and formation and injection of cooler vater into the twophase reservolr carrles the risk of reducing pressures due to stem collapse. Bxoadiands is two-phase largely because of its high noncondensible gas content (Grant, 1977) and the results of reinjection experinents here 111 be of interest to other two-phase reservolrs in the vorla. 
Reinjection experiments have been carried out at BR7, 13, 23, 28, 30, 33 and 34 as well as brief tests at other wells, Both hot and cold water have been injected. Many of these vells are producers and lie within the hot $\left(2260^{\circ} \mathrm{C}\right)$ part of the field. Eowever, B230 is nonproductive and has temperatures around $220^{\circ} \mathrm{C}$ and BR34 was a well intentionally crilled outside the field. In lts original injection conflguration BR34 had a depth of $400 \mathrm{~m}$ and was effectively cold (Interestingly this well has singe been deepened to 2600 meters and reached $300^{\circ} \mathrm{C}$. BR33 was also drllled as a shallow $(36 \mathrm{5m})$ reinjection well but lles in the center of the hottest part of the Eleld (see Fig. 1). Injection performance of each of these wells will be alscussed individually.

ER7

This $1000 \mathrm{~m}$ deep well injected for nearly two years in 1976 and 1977 (B1xley, 1978). Injection temperatures were $150^{\circ} \mathrm{C}$ for five months. then $120^{\circ} \mathrm{C}$ for flve nonths, then $110^{\circ} \mathrm{C}$ for ten months. Injection rate was about 30 tonnes/ hour throughout the test, except for several shut-in periods of up to a week for transient testing. The injected water was plped from $8 R 27$ and was supersatirated with siliea. Figure 2 shows the varlation of flow, well thead pressure and downhole pressure at 823 m depth during 1977. The breaks in the curves are where the shut-ins occurref. It is seen that both wellhead and lowhole pressures dropped steadily throughout this perlod even though infection rate was maintained - ease of injection was therefore markediy improved during the test. The suggested explasation for this is that the reservair fluid in the vicinity was originally two-phase, and cooling of the reservolr condensed some steam and lowered the pressure.

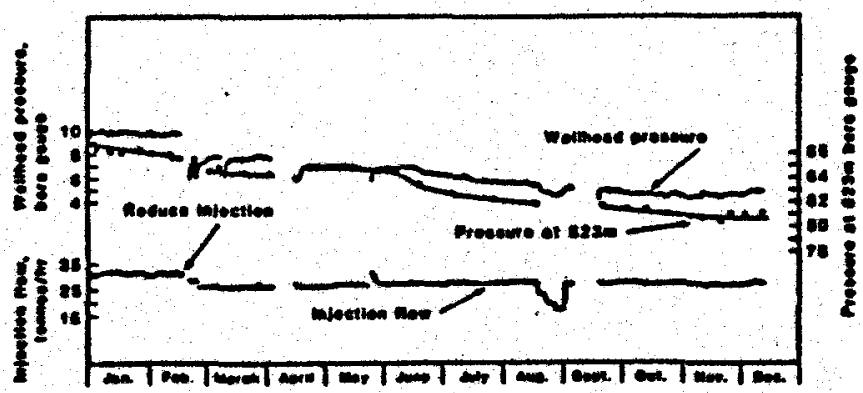

Figure 2: Injection performance of BRT during 1977, frow Bixley (1978)
It is not known where the water infected into BR7 went. In June of 1981 Iodine-131 tracex was infected Into BR7 (McCabe, Barry and Manning, 2982) in a forty day infection using water from BR27, but none was recovered in BR10, 16, 27, 29 or 36. There was a thermal effect on BR7 in the 1976-77 test, which was demonstrated by the reduction in enthalpy when the well was subsequently discharged after varm-up. It is not known whether this entralpy would have increased with time, since BRT censed production while its discharge enthalpy was etill low.

\section{BR13}

Nater at $98^{\circ} \mathrm{C}$ was pumped Into BRI3 at zates around 205 tonnes/hour from July to lugust 1979. The well is around $1000 \mathrm{~m}$ deep and has loss zones into the Rangitalk1 Ignimbrite at about that depth. The injection pump was stopped and restarted eleven times during the test, and pressure fallofts and bull dups were recorded. Analys is of these falloff tests (Grant, 1979a) showed that the permeabilitythickness product increased with injection. and Figure 3 shows this variation as a function of cumblative water injected. Inis increase in Infectivity is in spite of the fact that the water was supersaturated with silica. On the other hand, no reduction of downhole pressure was observed, indicating a different response to relnjection than BR7 although the duration of the test was very much shorter. The increase in injectivity (permeability) is probably cue to the opening of flssures by thermal contraction - this idea is suggested more strongly from the BR23 experience and will be discussed later.

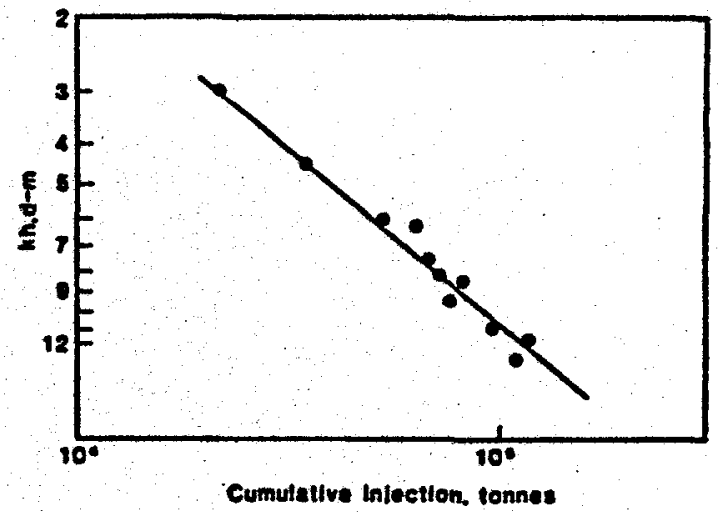

Figure 3; Permeability-thickness as a function of cumblative infection for BRI3, from Grant (1979a) 
The course of the injected water was determined to some extent by tracer testing. In o second Injection of 150 tonnes/hour of $160^{\circ} \mathrm{C}$ water in 1980, Iodine-131 was injected Into BR13 and wells BR19, 20 and 23 were monitored. Iracer was recovered in BR23 but not in 19 or 20 . despite the fact that $13,19,20$ and 23 are known to be in good pressure conmunication (Mccabe, Barry and Manning, 2981). BRlg was on foll discharge during the test (250 tonnes/ hour) supplying the water to BR13 but still did not induce a Elow underground Erom BR13. BR2O and 23 vere originally only on bleed Hows (around 1 tonne/hour) but 8R23 was opened to 47 tonnes/hour on the seventh day of injection when the bleed rate began to fall off. Tracer had already been retrieved at BR23 on the fifth day, peak arrival times indicate a transit speed of around $0.4 \mathrm{~m}$ /hour. Eventwally 6 of the tracer was recovered at BR23 although this figure may have been fifferent had the flow rate not been changed. BR23 feeds in the same Rangltaiki Ignimbrite as BR13, BR20 feeds in the next higher formation (the Rautawiri Breceia) and BRIg feeds in both the Rautawirl brecela and the much higher vaiora formation.

In March 1981 eixty-six tonnes (1.e., two wellbore volumes) of cold river water were injected into BR13 with a tracer slug, but no tracer was returned to elther BR19, 20 or 23 is the thitty days of monitoring. It seems evident then that the flow between 13 and 23 in the 1980 test was a result of the reinjection and not natural flow within the reservoix.

After injection the vell was allowed to warmup before discharge. $\lambda s$ in BR7, the enthalpY of aR13 was st111 depressed even after the varm-up. Indicating a thermal drawdown of the reservoir in the vielnity of the vell due to the reinjection. There vere no effects observed on the surrounding producers - the decline in production of BR23 mentioned above appears not to be attributable-to tooling of man Its inflow.

\section{BR23}

BR23 is a deep two-phase production vell of around $1000 \mathrm{~m}$ depth and 18 simflar to BR13. Spinner surveys curing Injection show that all infected vater is lost below $1000 \mathrm{~m}$, close to the botton of the hole. loto the Rangitaiki Ignimbrite, In June $1979,98^{\circ} \mathrm{C}$ water vas injected into BR23 for one veek at around 150 tonnes/hour. Four pressure translents were carried out after $1,4,6$ and 7 day: (Grant 1979b). The injectivity determined frcm these tests is plotted in Figure 4 , and is seen to increase uith increasing injection. It seems that this increase in injectivity is as a result of the opening of fractures cue to the injection. The well was left to warmup after infection and then produced; productivity was higher than before but fell during production. Injection then resimed; Injectivity was below its previous high, but above its earliest value, and again ircreased. This is shown in Figure $\mathrm{Al.18}$ of Grant, Donaldson and BLxley (1982).

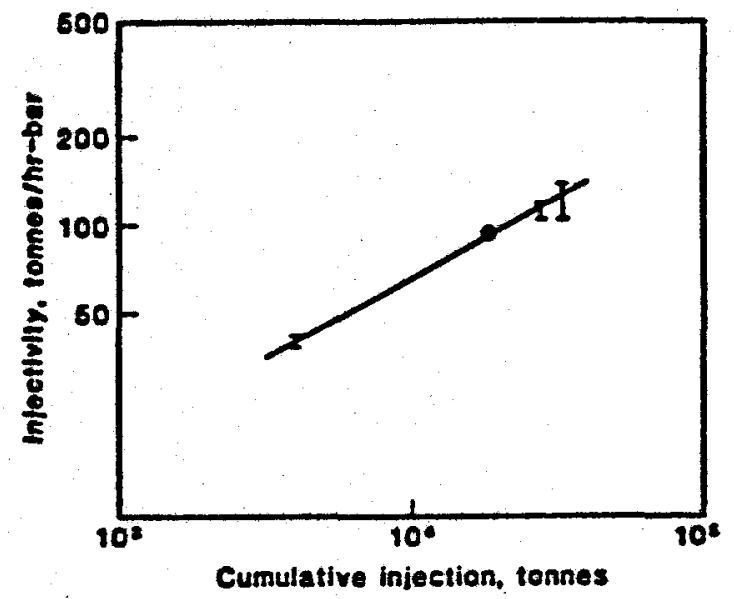

Figure 42 Injectivity as a function of eumuIative injection for Br23, Ercan Grant (1979b)

There were never any tracer tests performed at BR23 and therefore it is not known where the injected water went. Considering the observations of tracer return to $B 223$ from Injection into BRI3, it vould be very interesting to see if the reverse flow occurred. BR23 was able to discharge igain after a two month period of warm-up, although at a reduced enthalpy - $2110 \mathrm{~kJ} / \mathrm{kg}$ compared to 1 te orlginal enthalpy of $1320 \mathrm{~kJ} / \mathrm{kg}$. The enthalpy rose to $1190 \mathrm{~kJ} / \mathrm{kg}$ after two weeks of discharge (Grant 1980a). After second injection the enthilpy was recuced to 1030 $\mathrm{kJ} / \mathrm{kg}$ in subsequent aischarge.

BR28

BR28 is about 11000 deep and is a two-phase producer. 155 tonnes/mour of $155^{\circ} \mathrm{C}$ water vere injected between January and warch of 1980. The stable downhole pressure fell curing injection (see Fig, 5) and contirued to fall with injection shut down (Grant 1980b). Is in BR7 this seems due to the infection of cooler vater into two-phase conditlons, collapsing steam and hence lowering the pressure.

Iodine-131 tracer was injected into BR28 with 150 tonnes/hour of $160^{\circ} \mathrm{C}$ water from BR35 in November 1980. A small teturn was reselved at BR25 on the cixth day Indicating a speed of movement 0,8 m/hour. No returns were measured in 0235 or in any other monttored vel2. 
Br28 is the only well in New zealand which has been discharged imediately after injection. The discharge enthalpy was inftially that of the injected water. and slowly increased.

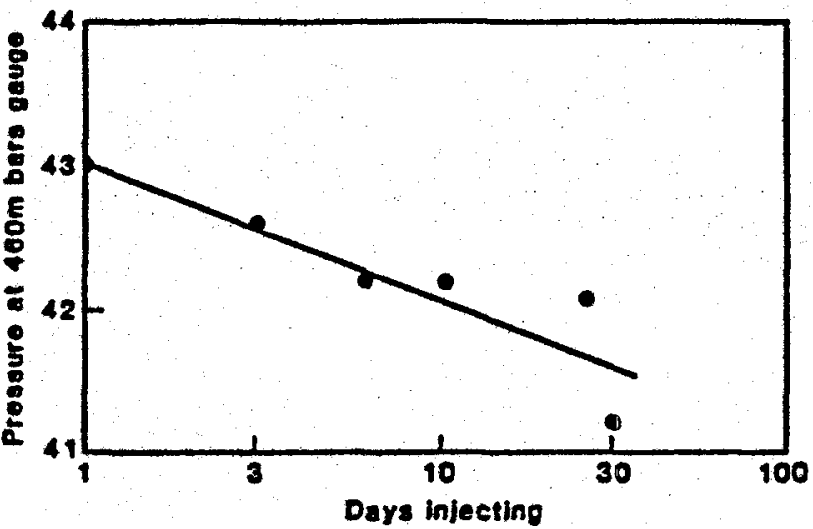

Figure 5: Reservoir pressure as a function of days of Infection for BR28, from Grant (1980b)

\section{$\underline{8 R 30}$}

BR30 was drilled in December 1975 and is generally Iisted as non-product ive, although it can afseharge at low enthalpy (930-980 kJ/kg). In august of 1980 atimulation experiment was carried out by Ministry of Works and Development in which 300 tornes/hour of cold water were pumped for about two weeks. Permeabllity (infectivity) was found to increase exponentially with increasing pressure (Grant, 1981a). At mall flows the permeability-thiekress product was about $0.1-0.3$ am bot at 400 -tonnes/. hovr it increased to over $10 \mathrm{dm}$. The increase was found to be reversible, that is, it went. away with reduction in pumplig pressure. This injectivity licrease, therefore, seens different fram those of BRI3 and 23 which are thermally rather than hydravileally produced.

A second test was carried out starting in February of 1981 in which hot water from $B R 35$ was infected at $130-180^{\circ} \mathrm{C}$. Injection lasted a period of months although rates were changed between 100 and 200 tonnes/hour. The inject 1vity/pressure dependence observed in the cold water tests was essentlaliy reproduced (Grant, 1981b).

Iodine-132 tracer was injected into $8 R 30$ in March 1981, and wells BR25, 27, 28 and 35 were monitored for five weeks. Ho tracer was detected at any of them.
BR33

gR33 was arilled to $365 \mathrm{~m}$ as an experimental shallow injection well in the center of the field. A reinjection scheme was run for six wonths in 1977 in which 300 tornes/hour of water from BRIl was discharged to $\mathrm{A}$ pond and subsequently pumped into BR33 at $80^{\circ} \mathrm{C}$.

In Hay of 1977. Iodine-131 tracer was injected into BR33 and vells BRII and BRB vere monitored. Tracer was letected in both vells. Travel time betweeen BR33 and BR2l was two days to the first appearance and eight days to the peak, giving a mean transit speed of 0.4 m/hour. Twelve percent of the tracer was recovered at BRil (Mccabe, Barry and Marning 1981). Five percent of the tracer was recovered at BRB; although the peak arrival was not until around 35 days. These recovery rates are unusually large compared to most of the other tests in New zealand (although not as large as some observed is Japan - Horne. 1982), and could indicate tendency for cold relnfected water to sink - BR11 is cased to $500 \mathrm{~m}$ and is only $75 \mathrm{~m}$ Iaterally separated from BR33. At the same time, an earlier cest in 1974 in which tracer was injected into BRII and detected in BRB without either well How ing indicated very inilar transit tires. The tracer response during the BR33 test conld therefore be affected by a natural flow vithin the reservoir.

The 22 tracer recovery at BRII also indicates that 12 of the 300 tornes/nour produced from BR11 originated at BR33 (this water was, of course, originally from BR1I and was thus recycled). The injected water was at $80^{\circ} \mathrm{C}$ and had little gas and higher chlorlde than the $245^{\circ} \mathrm{C}$ water produced originally from BRII. Surprisingly, there were no changes observed in the enthalpy or chemistry of the BRII difcharge (Grant, 1982a)... The water is-presum-ably reheated it it passes through the reservolr, but the lack of chemical variution is unexplained.

BR34

BR34 was arliled in 1978 as an experimental shallow, cold, peripheral reinjection well and at the tine of the infection tests was $40 \mathrm{~cm}$ deep. Water 1 rom $\mathrm{BRz}$ was separated at itmospherie pressure, but not exposed to the alr. and plped through an uninsulited pipeline neariy one (1) long to BR34. Two 400m deep clim-hole monitor vell vere drilled close to BR34, BRM2 is 45m to the north and BRM4 is $70 \mathrm{~m}$ to the southeast. Vater was injected at roughly $50^{\circ} \mathrm{C}$ at a rate of 160 tonnes/hour into BR34 for several months.

Quite different to the other reinjection tests. injectivity at sR34 declined spectacularly. and permeability of BRM2 and BRM4 al so de- 
Horne

clined. Clearly sillca was deposited within the BR34 wellbore and also far out into the formation. That this occursed at BR34 and not at the other sttes deapite the infected water also being supersaturated with silica in most of the other tests is probably are to the fact that infected water was reheated in time to prevent precipitation in the other tests (all of which were into high temperature formations).

Fracer injection into BR34 in Becember 1978 eraveled at $0.6 \mathrm{whr}$ to $\mathrm{ERH} 2$ and $1.2 \mathrm{~m} / \mathrm{hr}$ to BRM4. Nlthough only about it of the tracer was recovered, it is estimated that 75 s of the water airlifted from BRM2 and 50 of that from BRM4 originated from BR34 (Mccabe, Barry and Manning, 1981).

There were no thermal effects observed in the BR34 test since the injected water and formation were both cold.

\section{Walrakei}

In 1982, the f1rst reinjection tests have been performed at Wairakel, with vater from wR218 beling infected into mk220. However, some unintentional injection at wasrakel has been taking place for rome time. In 1969, production in wu101 (FIg. 6 shows well locations) ceased after a cownflow from a shallow feed zone at $360 \mathrm{~m}$ (Just below the easing shoe) to a deeper feed rone at $600 \mathrm{~m}$ depth...mC107. ceased probuction in 1976 and a downlow of $160^{\circ} \mathrm{C}$ water was neasured by splnerer at a rate of 300 tonnes/hour. wK80 still prodices steam from ground $300 \mathrm{~m}$ depth but has a downtlow of $175^{\circ} \mathrm{C}$ water from $350 \mathrm{~m}$ depth to $600 \mathrm{~m}$ depth. Other wells in the northwest corner have falled similarly over the yeurs and have been grouted up.

Extensive tracer testing in wc101, 107 and 80 was carzied out in 1978 and 1979 - (McCabe, Barry and Masning, 1980, 1981). In the three RK107 tests, the two deeper vells WK24 and wR48 rapidly returned 3.71 and 1.34 of the tracer respectively, with transit speeds of $22 \mathrm{~m} / \mathrm{hr}$ and $7 \mathrm{~m} / \mathrm{hr}$ respectively. The other wells monttored $(67,70,68,30,83,81,55$ and 108 ) showed returns between 0.1 and 0.38 with transit speeds around $1 \mathrm{w} / \mathrm{hr}$. These results are sumarized in Flgure 6 from Mccabe, Barry and Manning (2981), together with the wKOL and wKBO results. The results were reproduced over all three wx107 tracer injections (for those wells tested each $t$ ime) including the third test which tsed bromine82 isotope instead of the Iodine-13I used in all others. Figure 7 from Mccabe, Barry and Manning (1981) shows the wK24 remults for two of the tests.

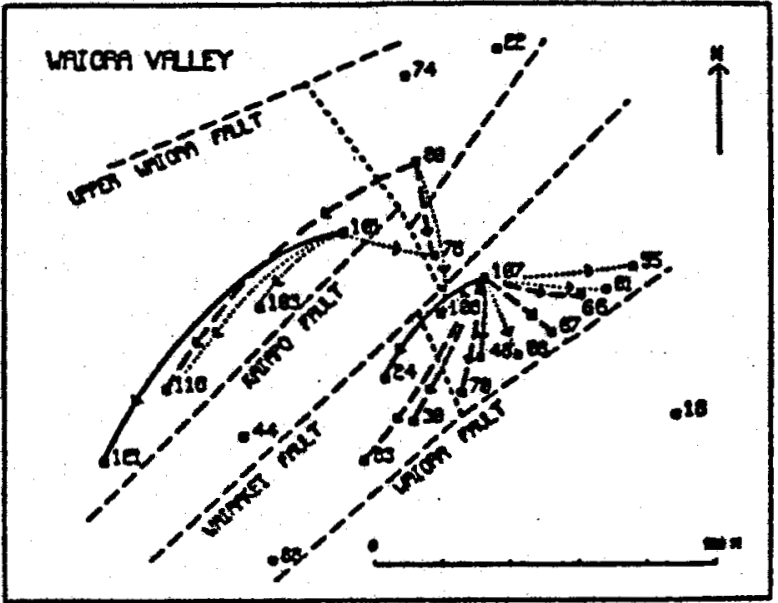

Figure 6: Tracer returns in the Naiora Valley section of Wairake1, Eron Necabe, Barry and Manning (1980)

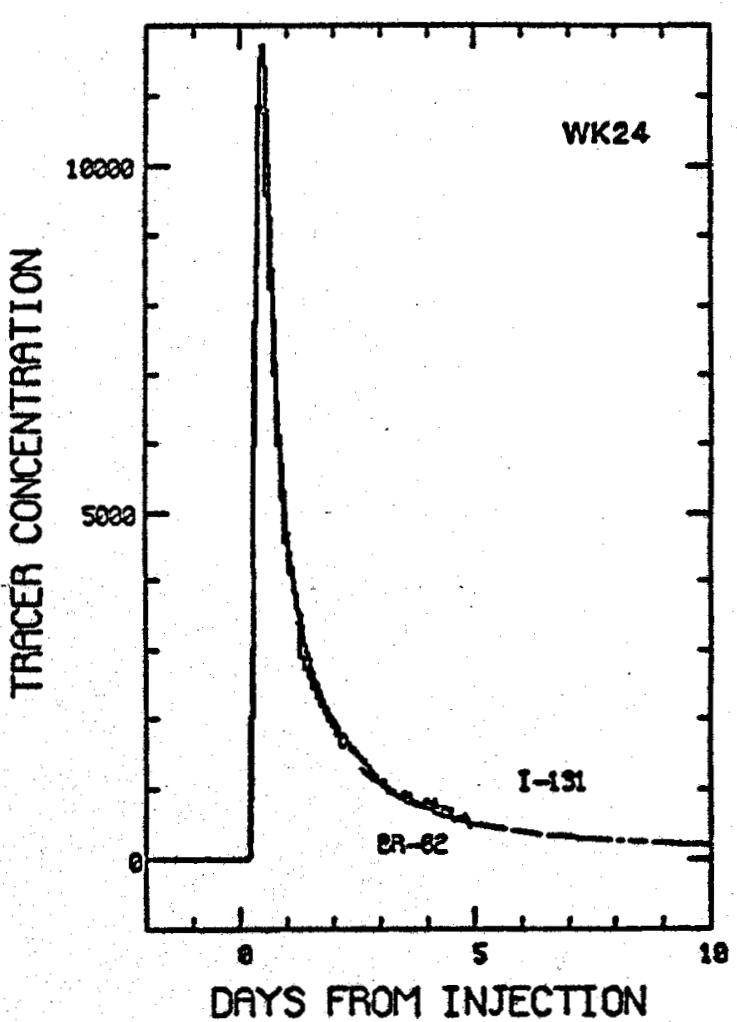

Flgure 7. Tracer concentrations at $\operatorname{MK24}$ due to infection into wa107. Two separate tests are with I-131 and the other with br-62. from Mccabe, Barry and Manning (1981) 
In 1980 kxa 107 was worked over and the offending upper feed zone was successtully sealed off. Surprisingly, after four years of accepting 300 tonnes/hour of $160^{\circ} \mathrm{C}$ water, the well agals produced at its earlier temperature. There is some evidence (Grant 1982b) that ink48 experienced an enthalpy crop of around $10 \mathrm{~kJ} / \mathrm{kg}$ and a wellhead pressure drop of 1 har (100 kpa) in 1976. Other wells in the vicinity do also appear to be negatively affected to a mall extent by the ix107 accident; however, the changes are only of simflar magnitude to normal operating fluctuations and are thus difficult to recognize. For the same reason, there have been no clearly cefined improvements since WR107 was repaired and placed back on production.

In the WK101 and wkBo tests the rather startling return patterns chow that infected vater noves in complex paths (see Fig. 6). Fracer injected into vklol arrived flrst at mi21 (the most distant) moving at $8 \mathrm{~m} / \mathrm{hr}$, second at wk103 (the elosest) moving at $1.3 \mathrm{~m} / \mathrm{hr}$ and last at wk116 (in a line between the other twol moving at $2 \mathrm{~m} / \mathrm{ht}$. Wk121 is a very deep well - the deepest at Wairakei - with 2250 in total depth, although it produces alinil from perforations at $975 \mathrm{~m}$ depth (still deeper than the usual 600 a depth in that areal. W0121 received 6 of the tracer infected at wK101 despite being 500 is dstant. It is not known whether MK121 has been affected by the wrl01 downflow since it was not dilled until after 1969, but there is an unusual $215^{\circ} \mathrm{C}$ temperature inversion in the well. wK121 could perhaps be made productive if WK101 were repaired. During the WKBO injection, WRI21 was not monitored as the separator installed to discharge it specially for the Wxi01 test had been removed. However, returns from WK80 to WK116 and MR76 were an order of. magnitude larger than those from ariol which leads to speculation as to what WxI2l may have show had it been monitozed.

The flow of relnfected water at valrakel is clearly within the faults although not necessarily by ilrect paths. The water from wolo? apparently moves down and to the southwest through the Nalrakel fault, being recovered first at $\$ \times 24$ which intersects the fault at around $760 \mathrm{~m}$. The Nalora fanlt meets the Walrakei fault at about 1000 m depth and the returns to $\mathrm{K} 48$ (which intersects the Valora Eault at $760 \mathrm{~m}$ (epth) and the other shallower and later-responding vells seew to be up the Waiora fault. This explains the roughly simultaneous arrival at all these vells (except for the ceeper MK48).

Sunmary

Reinfected water at Broadlands seems to nove through the reservolr at speeds around 0.5 in/hour indicating that reservoir short- circuiting my not be severe problem (tracer return speeds are similar to those observed at Otake in Japan - Horme, 1982). No thermal effects have been observed at nelghboring wells, although it is clear that in some cases quite Iarge percentages (up to 12t) of the reinjected vater a break through. Reservoir enthalpy is reduced in the vicinity of the injection well as expected, but the extent of the depression Is inited.

With the excoption of ar34, Injectivity increases is a result of temperature effect. (BRI3 and 23) pressure effects (BR30) or recuction in reservoir pressure (BRT and 28). The loss of reservolt pressure caused by injection into two-phase conditions should be avolded as the resulting pressure stak will reduce production in the vieinity.

The speeds of underground flusd novement at Walrakel are as much as 20 times greater than those in Broadlands, Indicating o greater potential for reservoir short clrculting during relnjection. The rapid pressure response ceross the fleld is a characteristic of Nairakel compared to Broadiands, although this alfference is also attributable to the large gas content at Broadlands (and corresponding high compressibility).

JAFAN

Japan has a vide range of geothermal power systems, Including vapor-dominated (Matrukawa), twophase (Onikobe), and compressec Iiquids (Onuma, Kakkonda, Otake, and Hatchobaru (see Fig. 8).

mour indicating that seservolr ghorto 


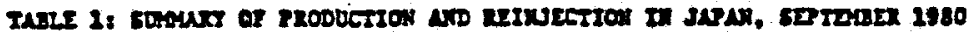

\begin{tabular}{|c|c|c|c|c|c|c|}
\hline \multicolumn{2}{|r|}{ Seacion } & anthobe & Teklonda & Oave & Inezbobers & Ocake \\
\hline & Capectey & $23=$ & $30 \%$ & $20 \mathrm{~m}$ & $33 \mathrm{~m}$ & $12 \mathrm{~m}$ \\
\hline \multicolumn{2}{|c|}{2980 rroduerson } & $7.5 \%$ & $-40=$ & $7 w$ & $53 \mathrm{mpr}$ & 22 \\
\hline 总 & $\begin{array}{l}\text { Wo. of will } \\
\text { Av. depes } \\
\text { Total stere } \\
\text { w.b.p. }\end{array}$ & $\begin{array}{c}22 \\
300 \mathrm{a} \\
75 \mathrm{k} / \mathrm{kx} \\
200 \mathrm{ks}\end{array}$ & $\begin{array}{c}21 \\
1000= \\
380 \mathrm{chc} \\
686 \mathrm{kP}\end{array}$ & $\begin{array}{c}3 \\
2600= \\
92 \mathrm{ent} \\
300 \mathrm{ks}\end{array}$ & $\begin{array}{c}B \\
2000= \\
400 \mathrm{e} / \mathrm{h}= \\
482 \mathrm{~kg}\end{array}$ & $\begin{array}{c}6 \\
500= \\
220 \text { shr } \\
306 \text { kea }\end{array}$ \\
\hline$\frac{8}{8}$ & 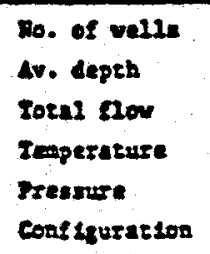 & $\begin{array}{c}2 \\
1000 \mathrm{a} \\
125 \mathrm{efh} \\
93^{\circ} \mathrm{C} \\
0 \\
\text { 14endos }\end{array}$ & $\begin{array}{c}15 \\
700 \mathrm{a} \\
2700 \mathrm{k} / \mathrm{hr} \\
-160^{\circ} \mathrm{C} \\
560 \mathrm{kPa} \\
=1 \times 2 / \mathrm{above}\end{array}$ & $\begin{array}{c}4 \\
800= \\
360 \mathrm{e} / \mathrm{hs} \\
95^{\circ} \mathrm{C} \\
0 \\
\text { sde/ebove }\end{array}$ & $\begin{array}{c}26 \\
2000= \\
100 \mathrm{a} / \mathrm{kx} \\
60 / 95^{\circ} \mathrm{C} \\
0 \\
\text { o1de/eques }\end{array}$ & $\begin{array}{c}8 \\
300= \\
680 \mathrm{e} / \mathrm{hr} \\
93^{\circ} \mathrm{C} \\
0 \\
\text { cdde/equed }\end{array}$ \\
\hline \multicolumn{2}{|c|}{ Braces bou rase } & - & s.e. & 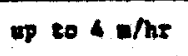 & up to $80 \mathrm{a} / \mathrm{hr}$ & $0.3 \mathrm{a} / \mathrm{hr}$ \\
\hline & Commenes: & Gus Isterfurence & - & - & ser1en senllos & $\begin{array}{l}\text { Aceepes vater } \\
\text { from natchobaru } \\
275 \text { eht }\end{array}$ \\
\hline
\end{tabular}

All the 1iquid-dominated systems have single flash steam generation schemes, with the exception of Hatchobart, which he double-flash system. A21 except hatsukawa have total waste ........ water reinjection schemes, necessitated primarily by enviromental requirements. Several alfferent reinfection configurations are in use, allowing an array of schemes to be evaluated. Each of the tlelas will be alscussed separately in cetail. but sumary data for all five flelds undergoing reinjection are Iisted in rable 1 for comparison purposes. Specific items of interest to th1s discussion are the quantity and tempecature of the reinjected water, the reinjection strategy used, and the observed effects on production.

\section{Onikobe}

Onikobe geothermal station in the Tohokn alstrlet of the island of Honshu is operated by the Electrie Power Development Company i led-(EPDC), and-has an installed capacity of 25 of. Iicensed capacity is $12.5 \mathrm{w}$, and actual production in 1980 was at $7.5 \mathrm{kH}$. Onlkobe 18 a very unusual fleld in that, at the targeted production depth of $1000 \mathrm{~m}$, highly aciaic water (pB 2.8 ) was intercepted. For this reason, a shallower, less aclafe (pa 5) production hor $1 z 0 n$ was tapped at $300 \mathrm{~m}$. The lower productioity of this upper horizon (around 10 tonnes/hour steam flowrate per well compared to 20 to 30 tonnes/hour at $1000 \mathrm{~m}$ ) is the reason for the reduced output from the station.

Production at Onikobe is from 22 wells at an average depth of $300 \mathrm{~m}$, although one new vell directionally drliled in 1980 produces pti 5 water from a 1000 in deep formation fpresumably different to that with of 2.8 vater). At the turbine inlet pressure of $200 \mathrm{kPa}(29 \mathrm{psig})$ the combined steam output from the wells is 75 tonnes/hour $(20.8 \mathrm{~kg} / \mathrm{sec})$. Water produced, added to the waste water from the station, makes ap atal of 115 tonnes/mour $(31.9 \mathrm{~kg} / \mathrm{sec})$ that is reinjected into a single well at atmospheric pressure. This single reinjection well is located at one end of the field (see Fig. 9), and has its fluid exit points in the 1000 a deep, acidic portion of the reservoli. This represents the nost desirable configuration proposed by Grant and Forne (1980) namely, a peripheral wel1, ceeper ethan the preduction depth.

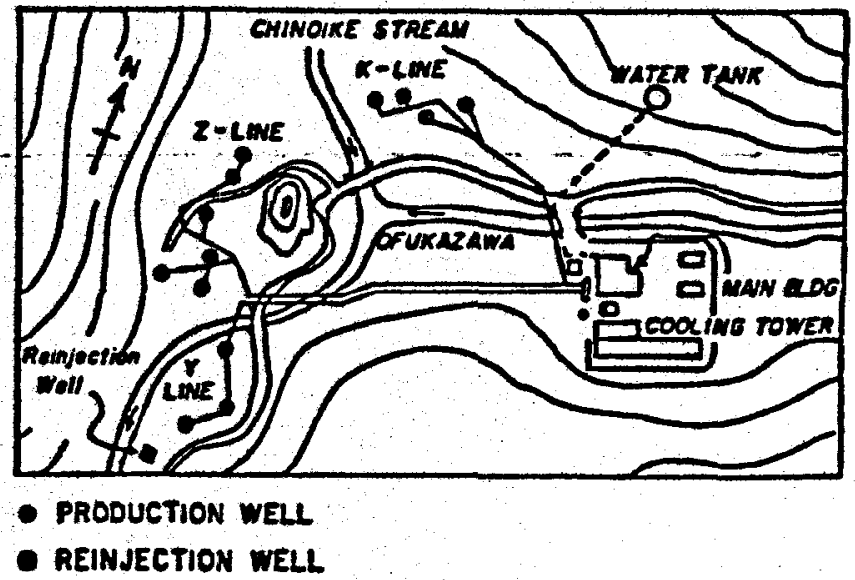

Figure 9. Sketch Map of Well Loeations at onikobe 
The performance history of the onlkobe fleld shows a decrease in the steam output frem the wells, but an increase in water output from about 60 tonnes/ hour in 1975 to 120 tonnes/hour in 1980 (see Fig.10). This effect way be due to the influx of colder vater from the surface. It could also be cue to the effects of reinjection. However, there has been no noticeable aditional alteration in the thermal or pressure behavior of the fleld since reinjection commenced in 2978 , and, In fact. the greatest increase in water production has been from " $\mathrm{K}$ " area, which is most distant from the reInfection site. On the other hand, there vas a distinct rise in the nitrogen content of the noncondensable gas production in the months following the start of reinfection. Inis rise in nitrogen content (which was accompanied by a fall in $\infty_{2}$ ) was attributed to the entraimeat of air into the relnjection vell (nmagal and Kawamura, personal communication, 1980). The reinfection wellhead consisted of a funnel arrangement into wich three hot vater pipelines exhausted. This arrangement was "boxed in" wring 1980 to prevent air entruinment, and the nitrogen content of the producing wells has since declined. Simllar transport of nitrogen has been observed at Hatchobari (Hirowatari, personal communication, 1981).

wot waren moduction ahte

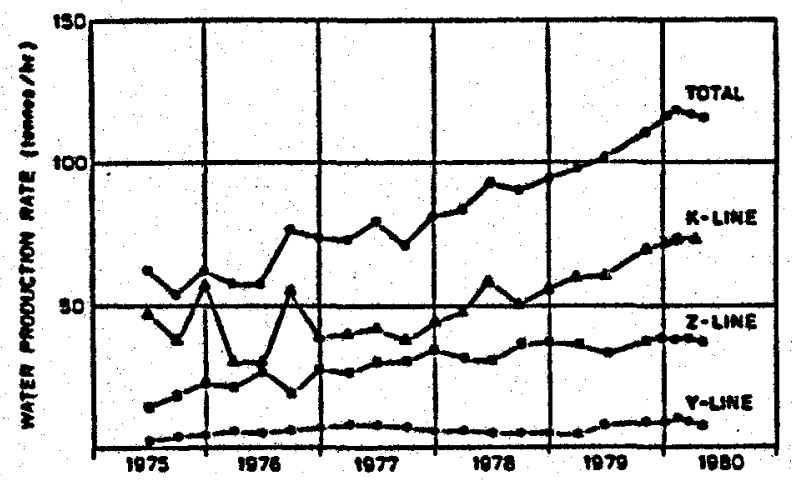

Figure 10. Changes in Itot water Production fate at onikobe

It seens then at least the noncondensable gases are moblle between the two reservolr levels at 300 in and 1000 a at Onikobe. This indicates permeable connection between them in spite of the water in the two reservolfs being chemicaliy very different. The fact that no thermal interference are to reinjection has been observed beyond the steady enthalpy decline already observed wile a hydraulic connection clearly exists way be wie either to the relatively short auration of injection, of to the fact that water is heated before reaching the production depth. In elther case, there was no obvious "short-circuiting" in the Onikobe reservoir as of August 1980. Although further observation is necessary (EPDC is invest1gating the possibility of a tracer, test). It currently appears that the "slde and below" reinjection configuration at onlkobe is woxking successfully.

\section{Takkonda (Takinoue)}

The newest geothermal power station in Japan, Xakkonda, is a $50 \mathrm{~mW}$ station operated by Japan Hetals and Chemicals Co., Itd. (JMC), and Tohoku Electric Power company. It has been producing since May of 1978.

The reinjection program at rakkonda is unusual in Japan in that the hot water is relnjected at separator pressure rather than at atmospherke pressure, as is the case everywhere else in Japan. Kakkonda is also unusual in the very large quantities of vater that are injected, the fleld enthalpy being rather 10w. The relnjection wells are "intermixed" with the production vells, but are scmewhat shallower depth (around $700 \mathrm{~m}$. compared to 1000 m for the production vellsl. Figure 11 shows the traces of the directionally drilled wells (JMC, 1978). Although the reinjectlon scheme could be broady characterized to be "Intermixedabove," there is in fact some degree of overlap between production and reinjection Ievels.

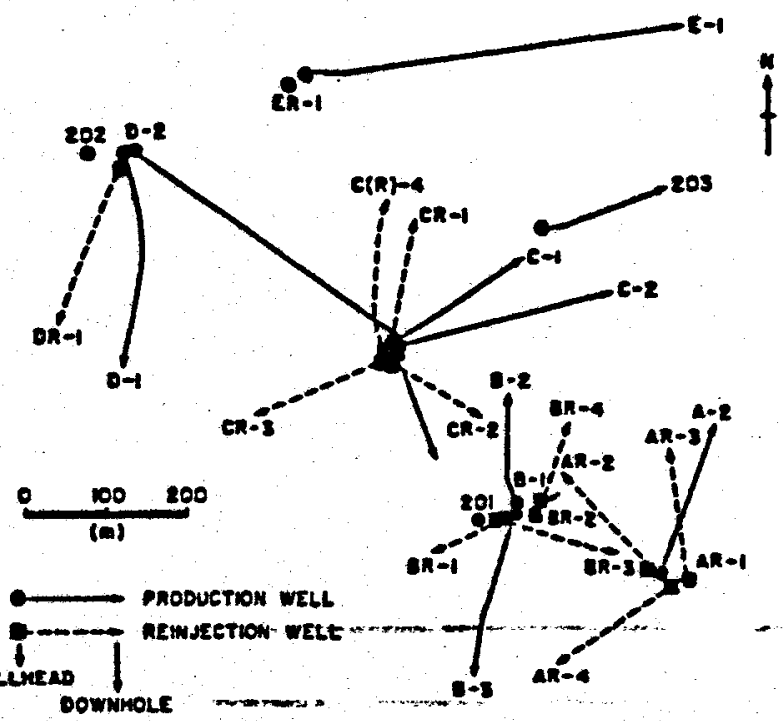

Figure 11. - Sketch Map of Ne11 Iocations at ..... Takkonda

The rery large quantity of vater injected at Kakkonda (3000 tonnes/hour for 500 tonnes/hour of steam produced) represents a "workt case" for reserwolr short-circulting. Such short-circulting has been clearly Identifled by tracer tests (Nakamura, 1981). Although station output remained essentially constant from startor (May 1978) unt11 July 1979, after that time it deelined rapialy from $50 \mathrm{wW}$ in July 1979 to $37 \mathrm{kw}$ In April 1981. Most producing vells maintained production or decreased only modestly during that period (see F19. 12) but vells which had rapid tracer arrival times from four particular injection wells declined significantiy in output even from the start of operations. Cessation of in- 


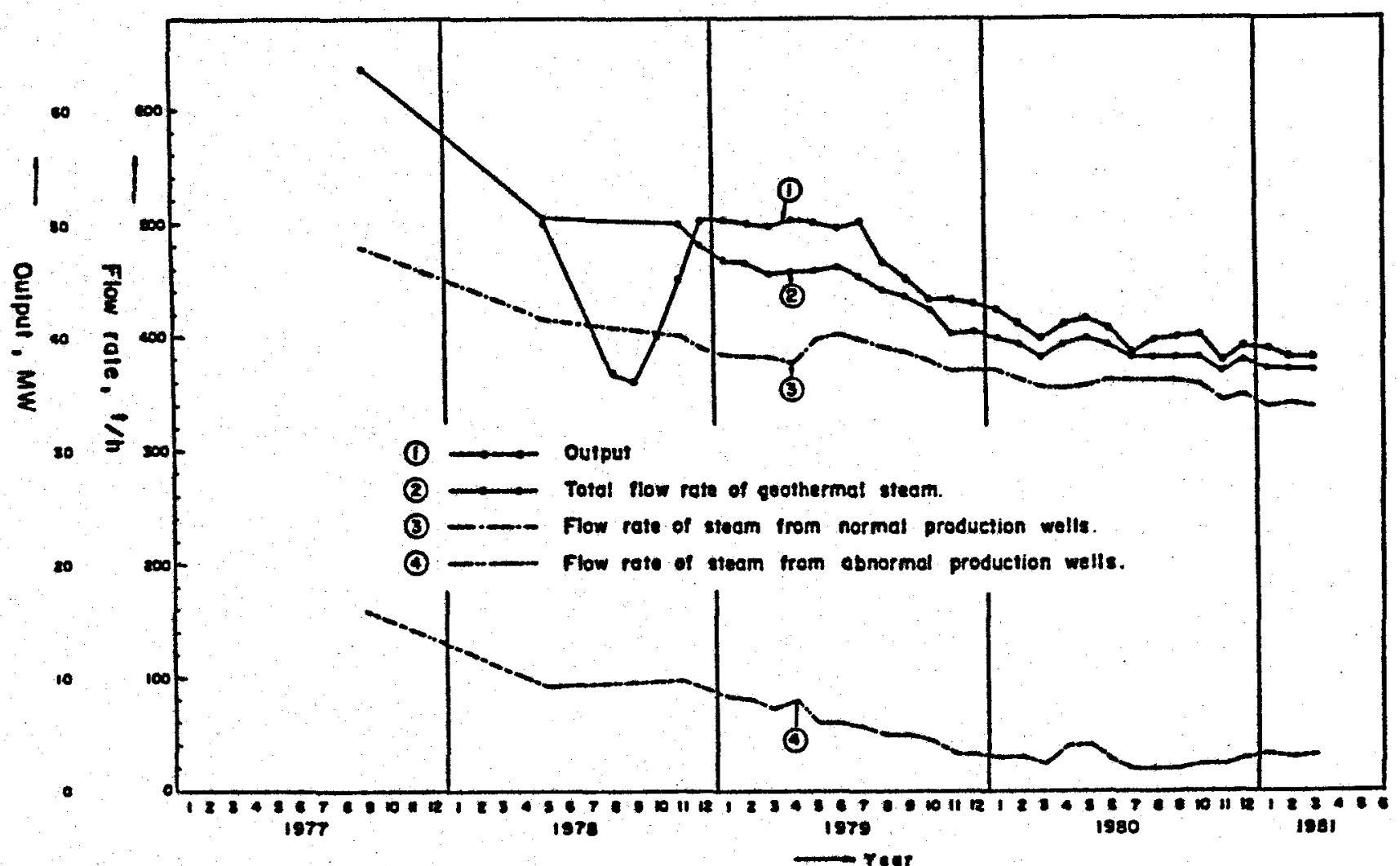

Figure 12. Changes in Total Output and steam Production Rate at Kakkonda (from Nakamura, by permission of Geothermal Resources Council)

fection into those four partleular wells resulted In a recovery of production to $41 \mathrm{~kW}$ by October 1981 (Nakamura, 1981).

Other than possible reservotr problens; injectton at separator pressure and temperature sems to have avolded wany of the depos ition problems. causing infectivity decline in several of the atmospheric relnjection schemes. This 1 s in 11 ine with the high temperature reinfection experience in El Salvador (Einarsson, Vides, and Cuellar, 1975) where 510 deposition was also successfully avoided. It has been ruggested that pressurized reinfection might induce on earthquake in Japan; however, extensive monitoring at rakkonda has shown no evidence of this (DI Rippo, 1980).

JWC Is investigating the possiblilty of reinfection at a remote heat exchanger site, in combination with direct uses of the recovered heat.

Onuma

The Onuma geothermal fleld is the site of the third geothermal power station completed in Japan. and began production in 1973. The plant has a rated capacity of $10 \mathrm{mw}$, and was bailt and operated by the MItsublshi Metal Corporation. Its output in 1980 was about $7 \mathrm{kw}$, down slightly fram $7.7 \mathrm{w}$ in 1977. Water is reinjected on one side of the fiela only, at somewhat shallower depth than groduction (see Fig. 13). An earlier report on reinjection experience at onuma by Ito, Iubota, and kurosawa (1977) Indicated that pressure-interference thed-oceorredi ir that-res-m-n ervoir presswres had been maintained. Water Elorrates actually increased while stegu clowrates rema ined the same indicating aet loss in proflucing enthalpy. Tracer injected into reinfection wells $0-7(T)$ and $0-7(R)$ was returned Into vells $0-6(R)$ and $0-3(R)$ a at such a level that to et al. (1977) calculated an intervening peimeabllity of 10 darcies, wich is clearly a high permeabllity connection compared to the rest of the reservolr. In more recent times. the same two wells $[0-6(R)$ and $0-3(R)$ a] have shown a greater enthalpy loss than other production velis and stean production rate has deel ined (Toto, 1980). Examination of the subsurface locations of these two wells (many of the vells at onuma are airectionslly arilled shows them to be closer to reinfection wells $0-7(2)$ and 0-7 (R) than the other producers.

Thus there is also evidence of "short-circuiting" during reinjection at onma, although to a lesser degree than rakkonda. In spite of higher conductivity zones in the reservoir tracer return rates are an order of magnitude slower than at rakkonda and it appears that reinjection and 
production coexist fafrly successfully, provtded wells are not too closely sited. MItsubishl Metal Corporation is cerrently ariling exploratory wells $1-2 \mathrm{~km}$ north of the power station in search of a more distant reinjection site.

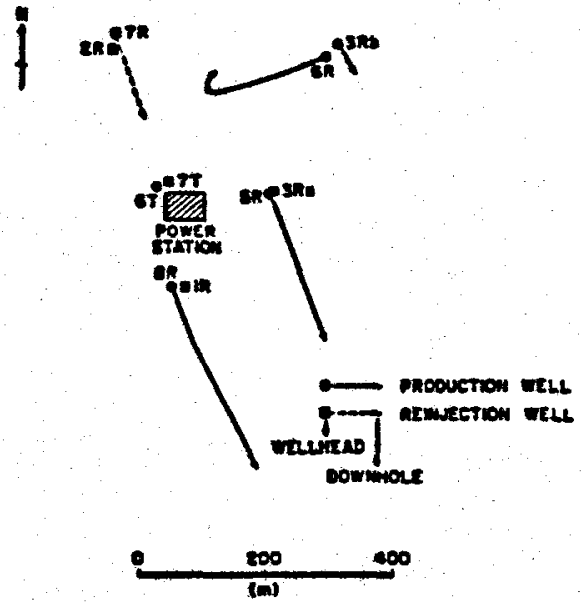

Figure 13. sketch Map of Well Locations at Onuma

\section{Hatchobaru}

Hatchobara geothermal fleld in the southern island of xyrshu has an installed capacity of $55 \mathrm{wW}$, and is owned and operated by the Kyusho Electric Power Co.. Inc. The plant was opened at approximately half capacity in 1977, and reached full capacity orly curing 1980 , obtainIng a sufflelent number of production and reinfection wells was partly responsible for the delay. The station is unique in Japan in that it uses double stage flash system that, in itself. precludes the reinjection of waste water at a pressure as hlgh as that at rakkonda. The reinjection and production vells are urranged roughly in a "side-by-side" configuration (Fig. 14) with reinjection in the northwest and production in the scutheast. heinject $10 \mathrm{n}$ and production deptis are more or less equivalent. This ruther musual arrangement was necessary simply because no other permeable level was located (Rayashl, Mfmura, and Yamasak1, 1978).

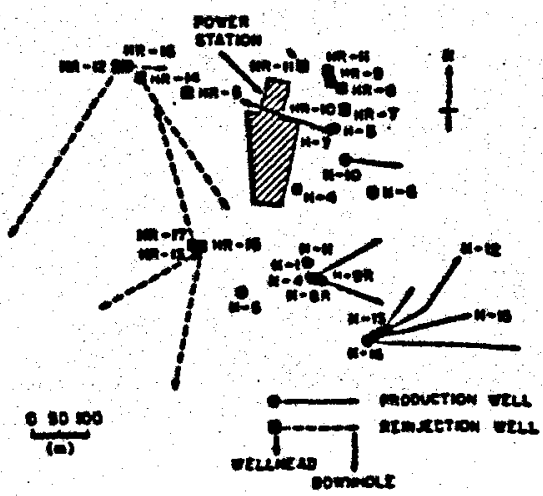

Figure 14. Sketch Map of well Locations at Hatchobart

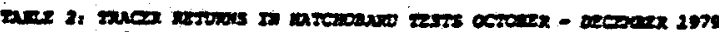

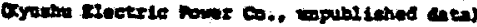

\begin{tabular}{|c|c|c|c|}
\hline $\begin{array}{l}\text { Ingecene } \\
\text { und }\end{array}$ & $\begin{array}{c}\text { Foosucing } \\
\text { ans2 }\end{array}$ & 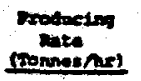 & 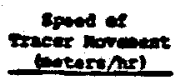 \\
\hline \multirow[t]{4}{*}{$m-27$} & \pm-7 & 227 & 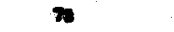 \\
\hline & $1-4$ & 240 & 76 \\
\hline & $=-13$ & 40 & 18 \\
\hline & $n+3$ & e.e. & 25 \\
\hline & -14 & $2 x$ & $\bullet$ \\
\hline & $=-10$ & 7 & - \\
\hline \multirow[t]{4}{*}{$m \rightarrow$} & $=-34$ & 226 & Is \\
\hline & $=7$ & 17 & 3 \\
\hline & $n=0$ & 100 & $\bullet$ \\
\hline & $=-11$ & $\bullet$ & 2 \\
\hline \multirow[t]{3}{*}{$x \rightarrow x$} & $=-23$ & 40 & $\infty$ \\
\hline & $=7$ & $2 x$ & $\bullet$ \\
\hline & $=4$ & 210 & $\bullet$ \\
\hline \multirow[t]{3}{*}{$=-300$} & $1-6$ & =... & 33.6 \\
\hline & $=-7$ & m.4. & .0 \\
\hline & $n$ & a.e. & 6.2 \\
\hline
\end{tabular}

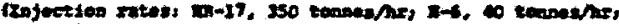

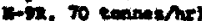

Gecendisy swem and

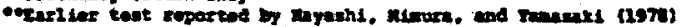

Extensive tracer tests at Eatchobaru by Xyushu Electric Power co. have indfeated strong connec tivity between come wells with actual speed of tracer novement in the reservoir as high as $80 \mathrm{~m}$ hour, with strong returns over cistances is far as $600 \mathrm{~m}$. Trble 2 shows the rates of return for the three tracer injection tests. Froduction vells $\mathrm{H}-4$ and $\mathrm{E}-7$, which both showed tracer returns in all three of the tests, have since shown a cecline in two-phase flowrate, particularly $\mathrm{H}-4$ wrich tas now ceased production al to gether.

Another problen with relinfection at Eatehobarn has been 20ss of infectivity, possibly due to - IIlca deposition since the hot vater is infected at atmospheric pressure and atr is entrained in scme of the older vellhead separator conflgura- tlons. In order to achleve sufflcient infection capacity to haintain $55 \mathrm{wh}$ of Electrieal generation and to avold thermal interference by reinjected water. 275 tonnes/hour of the 645 tonnes/ hour of waste vater are exported to Otake and injected thare. Krushu Electrle power $C o$. has successfully 1dentifled possible reservolr shortcircuiting problems using the tracer tests and has avolded the problems by injection at a remote site (Yoshida, 1980). Interestingly, trecer tests at Hatchobara are conducted extremely economically using Eluoresceln dye. Although the more expensive Potassium Iodide tracer has been used there it was determined that zluoresce in could easliy provide data on first arrival times wich are considered the most important parameters. 
Horne

Otake

Otake power station was the Eirst liquid-dowinated geothermal fleld under production in Japan, and the second such in the world. Owned and operated by the Krushu Electric Power Co., Inc.. it has a capact $t y$ of $12.5 \mathrm{~mW}$, and has been operating since 1967. Originally, the waste water was refected to a pond however, reinjection was started in 1972 to avoid chemical pollution we to the arsenic content of the water. Initially, an improvement of recovery was observed (Tubota and rosakd, 1975) Indicating the support of reservolr pressures, but by 1975 this inprovement ceased, and well $0-7$ (see Fig. 15) ceased production due to a $105 \mathrm{~s}$ in enthalpy (Onodera and Fukuda, 1976) Indicating thermal interference. Since that time, reservoir output has been declining at about the same rate (6t per year) as prior to reinjection (FIg. 16). In 1979 and 1980, production was ralsed to the installed capacity by the drilling of new production wel1s $0-14$ and $0-15$, and relnjection increased to a total of 663 tonnes/hour including 175 tonnes/hour of waste water piped from Hatchobaru.
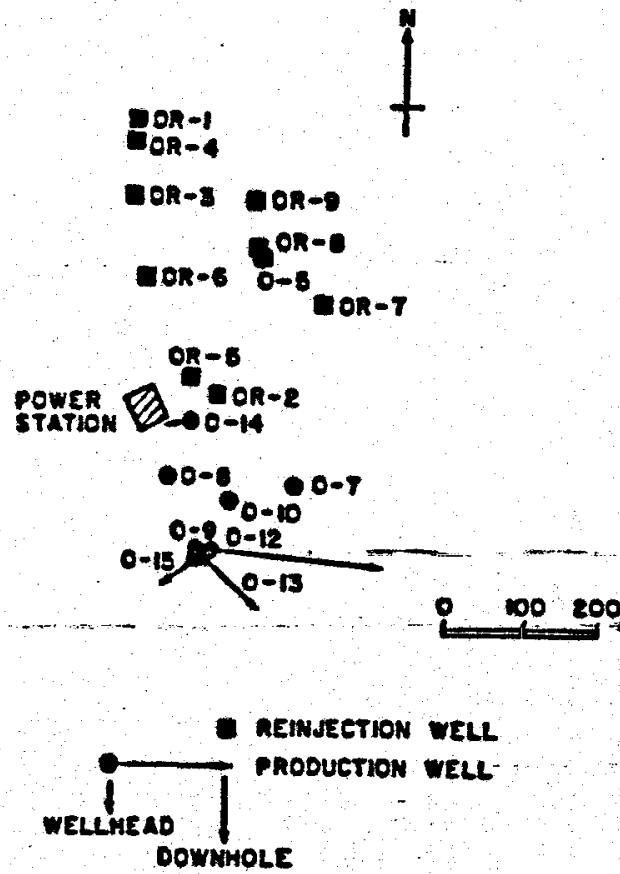

Figure 15. Eketch hap of Well tocations at oteke

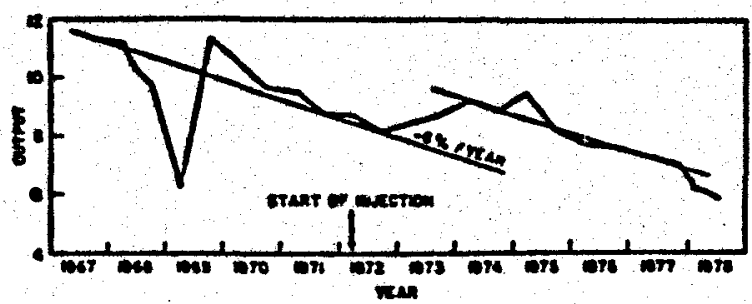

Figure 16. Changes in Total Electrical output at Otake
Despite the demise of well 0-7, reinjection appears to be very successful from a reservoly standpoint. Tracer tests performed at Otake by Xyrushu Electric Power company in 1976 showed tracer permeation speeds on the order of $0.3 \mathrm{~m} /$ hour (Bayasht, Mimura, and Yamasakt, 1978) which is two to three orders of wagnitude wailer than observed in Hatchobaru. Tracer vas infected into reinjection vell or-2 (see Fig. 15), and was detected in wells $0-8,0-9$. and 0-10 within about 600 hours. Tracer returns In the Hatchobaru tests vere detected as early as two hours after infection. It appears that interwell connectivity at otake is not high, and in fact, welle 0-9 and 0-10 continue to produce after seven years of reinfection into well OR-2, which Is 203 meters distant fram $0-9$, and 140 meters distant from vell $0-10$.

Otake does have a loss of injectivity poblem sinliar to that at Hatchobaru, probably ateributable to the supersaturated cillea conditions at itmospheric pressure. Xyushu Electrlc Fower Company is conducting extensive vaste water treatment stuales in attempts both to remove silica to avold injectivity problems and to remove ersentc in order to be able to arota reinjection altogether.

Summax

In cases where Inter-well klows do occur in Japan, the resulting thermal interference can be greatly detrimental to the performance of the producing we11. Specific instances of wells themally influenced (wentioned in thts paper) include well 0-7 at Otake, wells $\mathrm{n}-4$ and $\mathrm{k}-7$ in Hatchobara, wells $0-6(R)$ and $0-3(R)$ a at onuma and several unnamed wells at Kakkonda. On the other hand. the hydraulic interference way be beneficial in provicing pressure support. The problem is ane of removing the reinjection well to such a dstance that the cooler reinjected water is re- heated before arfiving at the producing well. Previous estimates of the "safe- alstance" heve varied. Hayash1, Himara, and Yamasak1, (1978)

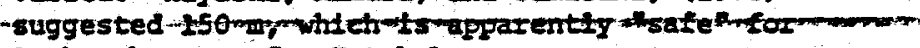
Otake, but not for Hatchobart.

Malntenance of reservolr performance by relnjection may indeed be beneflelal, however in Japan. only a cingle example of performance improrement three examples of reduction in performance by thermal interference have been observed (Batchobaru, rakkonda, and onuma). If priorities are to be allocated, in highly fractured oystems it appears to be expedient to avold themal Interaction even at the cost of losing hydraulic oupport. One attractive method of achiering this Is to inject at a neighboring but separate site.

Tracer testing has been used to great advantage in Japan and has helped IdentIfy and overcome some of the reinfection breakthrough problems particularly at Xakkonda. Both the results and the tracer test themselves contrast with those described earlier in New zealana. Radioactive 
tracers were used exclustvely in New zealand whereas chemical tracers were used in Japan. In addition, the percentages of tracer recovered in Japan were much higher - up to 35 (Sunshine Project. 1980), and speeds of underground wovement were much faster - as high as $80 \mathrm{~m} / \mathrm{hr}$ (see Table 2).

Loss of injectivity has proved a dfficulty in Otake and Hatehobaru. It is not clear why the alica supersaturation provoes problematic in Xyushu but not in other flelds (New zealand for examplel, but saller clowrate seems to be a alstinguishing difference. Rakkonda has few infectivity problens with its pressurized higher temperature reinjection.

\section{SALVADOR - Ahuachapan}

El salvador generates a subtantial parcentage of its electricity requirements frcm geothermal energy at the 95 power station at Ahuachepan (Cuellar, Choussy and Escobar, 1981). Nell depths are between 600 and 1000 meters depth and uspally have an enthalpy of between 1000 and $1200 \mathrm{~kJ} / \mathrm{kg}$. Ne11s $\lambda_{h}-6$ and $\lambda_{h}-26$ eppear to have greater fxactions of steam in theif feeds, and huve enthalpies around $1500 \mathrm{~kJ} / \mathrm{kg}$. $\mathrm{A}$ well wap. Is shown in FIgure 17.

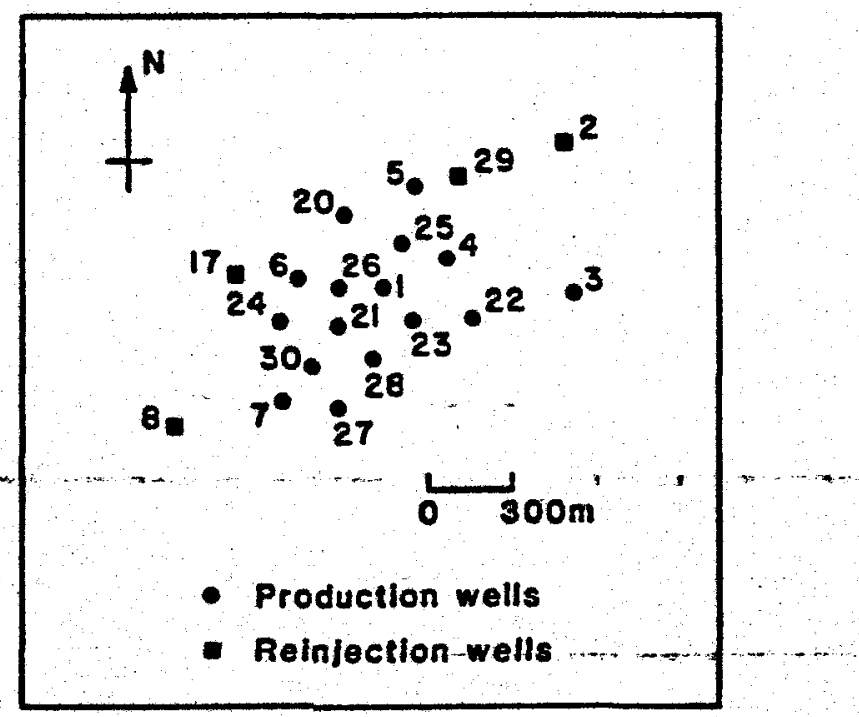

Figure 17. Sketch Nap of Well Iocations at Ahuachapan

A reinjection program commenced in 1976 and presently 40 of the produced fluid is reinjected Into wells $\mathrm{Ah}-2,8,17$ and 29 . Wells $\mathrm{Ah}-2$ and Ah-8 are drilled away Erom the production zone. but $A h-29$ and more particularly $\lambda h-17$ are close to the production wells. The water is injected at separator pressure (argund $540 \mathrm{kPa}$ gauge) at a temperature around $160 \mathrm{C}$. Keeping the temperature high has apparently avolded problems of s11lea deposition and there is some indieation that the injectivity of $\mathrm{Ah}-17$ increases. At a pressure of $590 \mathrm{kPa}$ in October 1976 ih-17 accepted 167.1 tonnes/hour of water, but by December 1977 accepted 473.2 tonnes/hour at a pressure of $610 \mathrm{kPa}$ (Cuellar. Choussy and Escobar, 1981). There was aso evidence of inprovement of injectivity in early relnjection tests into Ah-5 in 2971

(Elnarason, vides and cuellar, 1975).

The paths of the infected vater have been determined by repetitive chlorice analyses of the production vells. The water infected into Ah-29 seems to nove both to the cast and also towards the center of the field. On thic other hand water injected into $\mathrm{Ah}-17$ moves towards the center of the fleld. In 1971 a tritiun tracer injection into well ah-5 (which is a production vell but was used experimentally for refnjection) indicated returns to vells $A h-1, A h-6$ and $M h-7$. Nell Mh-1 responded within two days, indicatiag a speed of tracer flow around 8 mhour, but wells th-6 and $\mathrm{xh}-7$ ald not respond for several weeks and after three nonths had st111 not reached a peak of tritium concentration. There is, therefore, clear evidence of channeling in the reservolr, but not untfocmly.

The effects of reinjection have been a general support of reservolr pressures (Cuellar, Choussy and Escobar, 1981) although the cecrease in pressure decline nay also be cue to transition to two-phase conditions in the reservoir (Grant. 1980c). Temperature effects have been more alfflcult to recognize, Ah-5 was thermally zeduced by the reinjection in 1971 , but regained its earlier discharge enthalpy after coughly the same time as the duration of the injection tests. since full scale reinjection has been undertaken, there are some Indications of thermal infivence at wells $h_{h-6}$ and $\lambda h-24$ we to reinjection into $\lambda_{h-17}$, although this effect could also be attributed to bolifing in that vicinity since the temperature in ih-6 also cecreased prior to reinjection. There Is scme suggestion liso of a temperature effect on

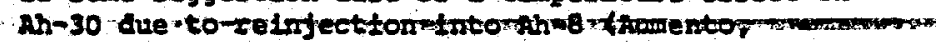
Iiguor1, Choussy, Santana, Campos and Escobar. 1982).

Suminary

Loss of Injectivity has not been a problem in $\mathrm{E}$ Salvador, and reinjection seems generally to have rupported fleld performance. Chanrieling has been seen to occur in the fleld, and there are Indications that more recently thermal breakthrough has occurred. Tracer tests and repeated chemical sampling shows the Ieinjected vater to be moring into the production area from vells Ah-17 and Ah-29.

\section{TAE PHILIPPINES}

The Republic of the Phillpptnes has undertaken a very ggressive geothermal development pollcy since the early $1970^{\prime}$ 's and has rapidily risen to be the largest producer of electrical power from ilquid-daminated geotherwal resources in the world. 
There are volcanoes and geothermal fields distributed throughout the nany 1slands of the Philippires and development is continuing at a zapid pace. Of the flelds is production or under construction, Mak-Ban in Iuzon and Tongonan in Leyte have undergone reinjection. At $220 \mathrm{~kW}$. Mak-Ban is the largest geothermal station in the world undergoing reinjection of wastewater. Reinjection is into 14 vells, wost of them in the periphery of the producling area (Rauseh, 1980). By December of 1980 over 15 million tonnes of wastewater had been injected without any observable negative effects (Raasch, 1980). No other published results of this reinjection scheme could be located, so Mak-Ban has not been included in this comparative sumary.

\section{Tongonan}

The rongonan geothermal field is situated in the Bao river valley on the island of leyte. Exploration drilling began in 1973 and the lirst deep well (401) was completed in Janurry 1977 to a depth of 1942 in in the Mahiao sector of the reservoir. The maximim downhole temperature vas $324^{\circ} \mathrm{C}$ and the well was connected to 3 w backpressure turbine in Jwly 1977 to generate electricity for the project and for the city of 0 rmoc $20 \mathrm{~km}$ away. Since that time, around 45 wells have been drilled at Tongonan, and a 112 MW power station will enter service in 1982. D1 charge enthalpies vary from 1200 to $2500 \mathrm{~kJ} / \mathrm{kg}$ and most wells are substantial producers laround 72 tonnes/hour of separated steam).

Reinjection of the wastewater from the station seens the most viable alternative for disposal as the exhaust rate will be around 1150 tonnes/hour of $160^{\circ} \mathrm{C}$ water (Dobble and Menzles, 1979a, b). The reservolr fluid contains epproximately 12,000 pom dissolved solids and after flashing and separation the reinjected water will have higher concentrations. - Reinjection testing has been carrled out since February 1978, with well 4 RI iccepting wastewater from the 3 w plant (Dobble and Menzies; 1979a), and en injection experiment into well 222 was carried out for flve months in 1981 (Sarit, 1981). A third test was also carried-... out in which water was infected into well 105 (PNOC, 1981). The results of-these three-injections will be-discussed here;-A nap of-we12-10cam tions is shown in Figre 18.

\section{RI}

Wastewater at $170^{\circ} \mathrm{C}$ was Injected under pressure from the $3 \mathrm{w}$ plant into 1 Rl from rebruary 1978 ont11 June 1980, then from September 1981 unt 11 the present. Nell 402 upplied steam to the plant unt11 January 1979, after which vell 404 was used. In March of 1981 the station stean supply was again switched back to vell 401 . Injectivity of well $4 R 1$ was found to incresse with cumulative volume infected, in a manner similar to that found in Broadlands welis in New zealand. This is shown in Figure 1 of Dobbie and Menzies (1979a). In addition, there was a drop in downhole pressure

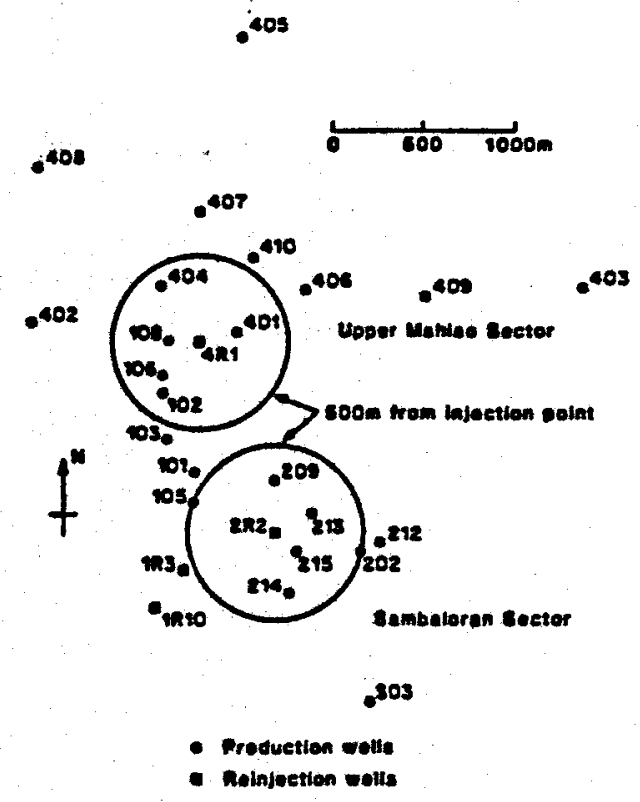

Figrze 18. Tongonan Geothermal Fleld

during the 401 infection, although this could be due to the reduction in water injection rate as 401 alscharge enthalpy increased during production.

In June 1981 Iodine-131 tracer was infected into well $4 R I$ (FNOC, 1981), and was recovered at wells 404, 401 and 108 . Each return was characterized by two or more peaks, and a total of 16.29 of the tracer was recovered. A total of 11.45 was recovered in 404 , with the speed of arrival of the first peak around $57 \mathrm{~m} / \mathrm{hour}$. A total of 2.841 was recovered in 401 , with the speed of urrival of the Eirst peak around 30 m/hour. Nell 108 recelved about 2 of the tracer with a flrot peak arxiving at around 22 anhour (PNOC, 2981)?

With such large und rapld tracer returns-and the Itve years injection into $4 \pi 1$, it is interesting to examine the effects on the-reservolr perfor-

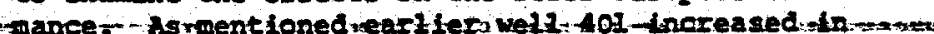
enthalpy as it was beling probuced, and strangely Aso while it was shut in between January 1979 and varch 1981. When restarted in kareh 1981. well 401 had almost doubled Its flowrate and, when back pressured to expply the 36 tonnes/hour of separated steam to the power plant. had a vellhead pressure of $5000 \mathrm{kpa}$. Since being reconnected to the plant both enthalpy and wellhead pressure have been slowly reduetng. It is alfelcult to find an explanation of this behavior consistent with any known effects of reinjection, and the performance changes are attributed to feed zone internetions within the vellbore (which are a comon confusing influence in fractured systems and particularly so at Tongonan). 
Well 404 has exhiblted a more normal response, and experienced an enthalpy decline during reinjection. This is consistent with the results of the tracer test.

\section{$\underline{2 R 2}$}

In the Sambaloran rector test in the firgt part of 1981, more than 800,000 tonnes of $160^{\circ} \mathrm{C}$ water vere reinfected into $2 R 2$ fram wells 202 , 209, 212, 213 and 214. The flve production vells vere not produced simultaneously but one, two or three (and on one occasion four) at a time (Sarit, 1981). The average flownte throughout the testing was around 200 tonnes/hour. Analysis of two-rate transient pressure tests during reinjection and fall-off tests after reinjection did not indicate any change in permeability of 282 (Sarit, 2981).

Iodine-131 tracer was infected into $2 R 2$ on 28 March 1981 and again on 20 June 1981 (PNOC, 1981). In the yarch test wells 202, 209, 212, 213, 214, 303 and 101 were monftored, and positive returrs were measured in vel1s 202, 209, 212 and 213. In this test the tracer was released into the upper feed zone $(400 \mathrm{~m})$ in 222 . In the June test, the tracer was released into the lower feed zone $(1300 \mathrm{~m})$ in 222, and vel1: 213 and 214 vere monltored.

net recovery at 213 was 0.34 in the Jure test, with peak arrival at 29 hours (around $10 \mathrm{~m}$ (hour). whereas, in the March test 1.68 of the trecer was recovered but the first peak ald not arrive unt 11 4.4 days (around $2 \mathrm{~m} /$ hour). In the March test, all of the indicated underground tracer arrival speeds were of the order 1-2 m/houx.

No published observations of the reservolr effects of this reinjection were found.

\section{5}

The 105 infection mentibred in Dobbie ard Henzles (1979b) was intended to investigate the effects of a higher degree of ollica supersaturation. vell_ 3 . 103 was probuced and back pressured to reduce separator presture and temperature- $A 5$ - conse-

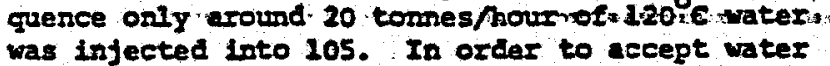
at such low pressure, well 105 was quenched with river water for almost as long as the reinjection duration, so in Eact the lofection test was much larger than is outwarelly epparent. When vell 103 water was then injected into 105, injectivity declined in 105 within one month. The well recovered on subsequent discharge, however, and after a second, short river water quench accepted water from 101 and 103 together at a larger flowrate. In this second test injectivity decline was slower, lndicating an inverse dependence on Elowrate.

No tracer test was carried out at 105 and no influence on the production wells observed.

\section{Summary}

Onderground fluid movements in Tongonan geothermal reservo ir are at rates is large as those in rakkonda and Batchobarr in Japan, and the potential for prenature themal breakthrough, therefore, seems high. Experience with well 404 also appears to indicate this. Interestingly tracer returns seem faster in the developed sector of the reservoir than the sector under testing. although the amount of data avallable is insufficient to assert this with confidence. The experfence of the two tracer tests into $2 R 2$ emphasizes the effects of fractures in reinjected water breakthrough, since tracer ceturns vere distinctly different when injected into aifferent fractures intersecting the same well.

Injectivity at Tongonan coes not seem to be a problen when reinjection is at separator pressure, but deposition occurs at lower pressures. Increasing flowrate seems beneficial in reducing silica deposition. This experience is very similar to that observed at Broadlands.

\section{concrostons}

1. Loss of infectivity to to siliea deposition has been successfully arolded in Hew zealand. Japan, El Salvador and the Philipplnes in cases where reinfection is under separator pressure and temperatures in excess of $150^{\circ} \mathrm{C}$. Lowering the temperature below $100^{\circ} \mathrm{C}$ has produced infect ivity losses in sereral places. but not elways. Injeeting at high rates into hot formatlons seens berefleial, presumably because the kinetics of the silica deposition are sufficiently slow to allow temperature and divtion to undersaturate the vater before nieleation oceurs.

2. In most places, Injectivities have increased with injection, et ther by the opening of Iractures due to thermal contraction or by pressure inflation of the sractures.

3. Injection of cooler vater into two-phase reservolrs has in scme-cases produced a-redus- tion in reservoir pressure. This is to be avotald in the design of a reinfection schene. $1 \rightarrow 0$ as

4. Irecer testing has shown that underground Eluid movement can be aubstantially altered by reinjection.

5. Collating all tracer experiments ficm both producting and nonproducing flelds suggests that nonproducing fields tend to how slower zates of tracer retorn. The body of data is not yet-large enough to confim this, but if true the predletion of reinjection breakthroughs fram pre-probuction tests could be a serlous difflearty.

6. Chenleal, short-1 fred radioactive and longIived radioactive tracers have 11 been successfurly used in fractured geothermal 
reservoirs. It is worth noting that radioactive decay and chemical reaction would probably render the fluorescent dye, hallde ion and short-1ived radioactive tracers useless were it not for the very rapid recorerles seen in fractured systems.

7. There appears to be a correlation between tracer return rates and subsectuent therwal breakthrough in the field.

8. Relnjected water tends to follow faults, but not recessarily in alrect paths. There is a tendericy for vater to move downwards but this can be overcome by vigorous production close by.

\section{ACKANOKLEDEVIENTS}

The data in this paper have been collected frem a very large number of sources and great many people. Listing individuals' names would be very lengthy, but I world Inke to acknowledge the help of the following organizations:

(New zealand) Dniversity of Auckland, Ministry of Works and Development, Department of Scientific and Industrial Research - Applied Kathematics Diviliton and Institate of Nuclear sciences, and Xingston, Reynolds, Thom and Mllardice, Itd, (Japan) Oniversity of Tokyo, Kynshu Unlversity, Electric Power Develogment Co.. Ltd.. Japan. Metals and Chemicals Co.. Itd., Mitsublehl Metal Corporation, Mippon steel Corporatton, Kyasha Electrle Power Co., Inc., Nest Japan Engineering Consultants, Ine.. and New knergy Develogment Organization; (Italy) EL-Electroconsult; (The Philipplnes) Philippine National oil Company and Phillpplite Geothermal, Inc.) (U.S.A.) Department of Energy and Union 011 Company. This paper was written under the auspices of the stanford Geothermal program which is funded by the 0.5 . Department of unergy Contract number DE-ATO3-BOSF21459.

PEFERENCES

IOSIR is an abbrevintion for the New zealand Department of scientific and Industrial Researeh, Nellington, New Zealand _.........

Aumento, F., IIgror1, R.E., Choussy, M., Santana, A., Campos, T., and Escobar, D., (1982). The Ceothermal system of the Ahuachapan Field," paper 85 presented at the International conference on Ceothermal Inergy. Morence. Italy. Hay 1982.

Bixley, P.F.. (1978), "Report on the Geothermal Waste water Into Broadiands Geothermal Field, New Zealand Ministry of Norks and Develoment Report, March 1978.

Cuellar, G., Choussy, H., and Escobar, D., (1981) "Extraction-Reinjection at Mhuachapan Ceothermal Field, El salvador, In Geothermal Systens: principles and case studites. L. Eyback and L.J.P. Muffier (Editors), John wlley, wew rork.
DLPippo, R., (2980), "Geothermal Energy as a source of Electricity," 0.5. Dept. of Energy, Nashington, D.C.

Dobble, T.P., and Menzles, A.J.. (2979a), "Geothermal Waste water Relnjection Trials. Hahido Reservolx, Republic of the Phillipines," Ceothermal Resources Councll, Mransactions. 3. p. 269-272.

Dobbie, I.P., and Henzies, A.J., (1979b), "Ceothermal Naste Water Reinfection Irials. Tongonan Reservolr, Republic of the PhL111pines, Proceedings, 1979 rew zealand Ceothermal Workshop, Auckland, New zealand, p. 134-140.

Einarsson, S.S., Vides-R, A., and cuellar, G. (2975). Disposal of Geothermal Waste Nater by Relinfection," Proc., 2nd 0.n. Symposlum on Geotheral Energy. San Francisco. Callfornta, 1349.

Grant, M.A., (1977), "Broadlands - I Gas" Dominated Geothermal Fleld," Geothermies. 6. p. $9-29$.

Grant, M.A., (1979a), "Injection resting BR13," New zealand Department of sclentific and Industrial Research, Applied kathematics Division (DSIR-AMD), memo.. October 1979.

Grant, M.A., (1979b), "Injection Testing Br23," DSIR-AND meno.. Kingust 1979 .

Grant, M.A., (2980a), "Injection and Discharge BR23," DSIR-AND memo.., Juse 1980.

Grant, M.A., (2980b), "Fall in Pressure ouring Injection at BR28," DSIR-AMD geothermal clreviar MAE29, Angust 1980.

Grant, M.A., (1980c), "simple Hodeling of Prounction and Reinjection at Ahuachapan,"

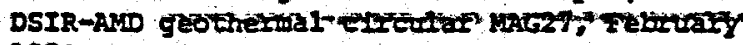
1980.

Grant, M.A... (1981a). "sttmulation Testing at

Grant, H.A.. (1981b). Wot Nater Injection at BR30," DSIR-ALD memo., Hay 1981.

Grant, M.A., (1982a), Interaction of Ohak1 Reservoir wth surcounding Fluid, DSIR-AKD, geotheral circular HaG37, Apri1 1982.

Grant, M.A., (1982b), Downflows in Welle nK80 and MK101," DSIR-AMD memo.. Kay 1982.

Grant, H.A., Donaldson, I.G., and Btxley, P.F.. (1982), "Geothermal Reservoir Engineering." Academic Press, New York, 1982.

Grant, M.A., and Horne, R.N., (1980), The Initial state and Response to Exploitation of Walrakel Geothermal Field," Geothermal Resources Counc11, Iransactions, 4, 333. 
Hayashi, M., Kimura, T., and Yamasaki, T., (1978), "Geological Setting of Reinfection Wells in the Orake and the Hatchobara Geothermal rield, Japan," Geothermal Resources Councll iransactions. 2.263.

Horne, R.N., (1982), "Geothemal Relnjection Experience in Japan," J. Petroleum Technologr. 34. P. 495-503.

Ito, J., Kubota, I., and Kurosawa, H., (1977), On the ceothermal vater Flow of the Onuma ceothermal Reservolr," Chinetsu (Ceothermal znergy). 14, 15 (in Japanese).

Ito, J., Kubota, I., and Kurosawa, H., (2978), -Tracer Tests of the Geothermal Hot water at Onuma Geothermal Field," Japan Geothermal Energy Assoclation Journal, 15, 87, In Japanese).

James, C.R., (1979), "Reinjection Strategy," Proc.. Sth stanford Geothermal Reservolr Engineering Workshop. Stanford, Callfornia, 385.

JMC, (1978), "Xakkonda Geothermal Power Plant," Japan Metals and Chemicals Co., Ltd., Tokyo, Japan (in Japanese).

Koto, K., (2980), "A Recent Aspect of Onuma Ceothermal power Plant," Chinetsv Enerug 11 (Geothermal Energy), 15, 50 (In Japanese).

Kubota, $K_{.}$, and Aosak1, $K_{.},(1975)$, -Reinjection of Geothermal Hot Water at the Otake Geothermal Field," Proc., 2nd v.N. symposium on Geothermal Energy, San Erancisco, California, 1379.

Mecabe, W.J., Barry, B.J.. and Manning, K.R., (1980), "Iracer Test - Wairake1," Institute of Nuclear Sciences Report INS-R-275, DSIR. July 1980.
Yccabe, M.J., Barry, B.J., and harning, M.R., (1981). "Radioactive Iracers in Geothermal Underground water Flow studies," Institute of Muclear Sciences Report INS-R-298, DSIR, October 1981.

Nakamure, H., (1981), "Develogment and ot111zation of Ceothermal Energy in Japan." Geothermal Resources Council, Iransactions. 5; 33.

Onodera, S.., and Fukuda, H., (1976), "A study of the Reinfection at the Otake Ceothermal Flela," rogaku shuho, (Technology Report, Kyoshu oniversity), 49, 829-835 (10 Japanese).

PHOC, (1981), "Reirjection Tests at Tongonan Geothermal stte," ph1lipptipe Rational o1l Company Energy Development Corporation ReDort, Mantla, Phillppines.

Rasseh, G.D., (2980), "An Overview of Geothermal Development in Tivi and Mak-Ban, Phlllppines," Proceedings, 6th Workshop on Geothermal Reservolr Engineering, Stanford, December 1980 , SCP-TR-50, P. 34-40.

Sarit, A.D., (2981), "Well 222 Reirjection Test Results, Tongonan Ceothermal rield, Republic of the Phillipines," Project Report Geotherm 81.19, Geothermal Institute, Oniversity of Auckland, New zealand.

Sunshire Project (1980), "Summary of Geothermal Energy Research and Development," Japan. Ministry of Trade and Industry Report. August 1980.

Thain, I.A., (1980), wairakei - The First Twenty Years," presented at the Electric Fower Research Instltute Geothermal conference, Monterey, California, May 1980.

Yoshida, K.. (1980), "Hatchobaru Ceothermal Power plant," Chinetsu Enerugil (Geothermal Energy). 15. 23 (1n Japaneset. 